\title{
WT1 immunoreactivity in breast carcinoma: selective expression in pure and mixed mucinous subtypes
}

\author{
Akosua B Domfeh ${ }^{1}$, AnnaMarie L Carley ${ }^{1, *}$, Joan M Striebel ${ }^{1}$, Rouzan G Karabakhtsian ${ }^{1, \dagger}$, \\ Anca V Florea ${ }^{1}$, Kim McManus ${ }^{1}$, Sushil Beriwal ${ }^{2}$ and Rohit Bhargava ${ }^{1}$ \\ ${ }^{1}$ Department of Pathology, Magee-Womens Hospital, University of Pittsburgh Medical Center, Pittsburgh, PA, \\ USA and ${ }^{2}$ Department of Radiation Oncology, Magee-Womens Hospital, University of Pittsburgh Medical \\ Center, Pittsburgh, PA, USA
}

\begin{abstract}
Current literature suggests that strong WT1 expression in a carcinoma of unknown origin virtually excludes a breast primary. Our previous pilot study on WT1 expression in breast carcinomas has shown WT1 expression in approximately $10 \%$ of carcinomas that show mixed micropapillary and mucinous morphology (Mod Pathol 2007;20(Suppl 2):38A). To definitively assess as to what subtype of breast carcinoma might express WT1 protein, we examined 153 cases of invasive breast carcinomas. These consisted of 63 consecutive carcinomas (contained 1 mucinous tumor), 20 cases with micropapillary morphology (12 pure and 8 mixed), 6 micropapillary 'mimics' (ductal no special type carcinomas with retraction artifacts), 33 pure mucinous carcinomas and 31 mixed mucinous carcinomas (mucinous mixed with other morphologic types). Overall, WT1 expression was identified in 33 carcinomas, that is, 22 of $34(65 \%)$ pure mucinous carcinomas and in 11 of $33(33 \%)$ mixed mucinous carcinomas. The non-mucinous component in these 11 mixed mucinous carcinomas was either a ductal no special type carcinoma (8 cases) or a micropapillary component (3 cases). WT1 expression level was similar in both the mucinous and the non-mucinous components. The degree of WT1 expression was generally weak to moderate ( $>90 \%$ cases) and rarely strong ( $<10 \%$ cases). None of the breast carcinoma subtype unassociated with mucinous component showed WT1 expression.
\end{abstract}

Modern Pathology (2008) 21, 1217-1223; doi:10.1038/modpathol.2008.69; published online 9 May 2008

Keywords: WT1; mucinous and micropapillary breast carcinoma; immunotherapy

Among normal human tissues, Wilms' tumor (WT1) protein is expressed at high levels in kidney glomeruli, gonadal ridge of developing gonads, sertoli cells of the testis, and both epithelial and granulosa cells of the ovary, suggesting a developmental role in both the genital system and kidney. ${ }^{1,2}$ WT1 gene is located on chromosome $11 \mathrm{p} 13$, and is primarily involved in the development of Wilms' tumor. ${ }^{3}$ WT1 immunoreactivity (for the C-terminal end) is also seen in desmoplastic small round cell tumor. However, in an immunohistochemical work

Correspondence: Dr R Bhargava, MD, Department of Pathology, Magee-Womens Hospital, University of Pittsburgh Medical Center, 300 Halket Street, Pittsburgh, PA 15213, USA.

E-mail: rbhargava@mail.magee.edu

${ }^{*}$ Current address: Department of Pathology, Regions Hospital, 640 Jackson Street, St Paul, MN 55101, USA.

TCurrent address: Department of Pathology and Laboratory Medicine, Chandler Medical Center, University of Kentucky, Lexington, KY 40536, USA.

Received 17 January 2008; revised 26 March 2008; accepted 31 March 2008; published online 9 May 2008 up of a carcinoma of unknown primary in an adult, WT1 is considered to be a highly sensitive and specific marker of mullerian serous carcinoma of ovarian, tubal, or primary peritoneal origin..$^{4-7}$ It is also highly expressed in normal and malignant mesothelium. ${ }^{8}$ Overexpression of WT1 mRNA in different types of hematological malignancies and solid tumors has been observed in recent studies. ${ }^{9-12}$ Current clinical trials have demonstrated WT1 becoming a molecular target for cancer immunotherapy; thus, its immunohistochemical detection in tumor cells is of clinical importance. ${ }^{13,14}$ Immunohistochemical expression of WT1 has been demonstrated in a few breast carcinomas in some recent studies. ${ }^{6,11}$ However, its expression in the different subtypes of invasive breast carcinoma has not been extensively studied. In a recent study by Lee et $a l,{ }^{15}$ WT1 nuclear expression was demonstrated in a minority of invasive micropapillary carcinomas. In a pilot study performed at our institution on WT1 expression in primary invasive breast carcinomas, we identified WT1 expression in $10 \%$ of tumors that 
showed mixed (MX) mucinous and micropapillary morphology. ${ }^{16}$ However, most of the pure micropapillary carcinomas were negative for WT1 and, in contrast, one pure mucinous carcinoma showed moderate degree of WT1 nuclear expression. This observation led us to examine WT1 expression in large numbers of pure and MX mucinous carcinomas of the breast.

In the current study, we have examined immunohistochemical expression of WT1 in a series of invasive breast carcinomas comprising of pure and MX mucinous types, pure and MX micropapillary types, and over 60 cases of consecutive breast carcinomas.

\section{Materials and methods}

\section{Case Selection}

The study was reviewed and approved by the Institutional Review Board. Cases were selected from the archives of the Department of Pathology at the Magee-Womens Hospital, University of Pittsburgh Medical Center. A total of 153 cases of invasive breast carcinomas were examined for WT1 expression in this study. Case selection was not random and can be grouped as follows:

Group $1(n=63)$ : These were 63 cases of consecutive invasive breast carcinomas. Of these, 54 $(86 \%)$ were ductal, including one pure mucinous carcinoma and nine (14\%) lobular carcinomas.

Group $2(n=26)$ : Cases in this group were retrieved by searching our pathology database of invasive breast carcinomas for 'micropapillary' and 'micropapillary features.' The cases were reclassified as pure invasive micropapillary carcinoma $(n=12)$, MX no special type (hereby referred as 'ductal' only) and micropapillary $(n=6)$, MX micropapillary and mucinous $(n=2)$, and remainder as ductal with retraction artifacts $(n=6)$. The classification was performed using previously defined criteria and also influenced by immunohistochemical staining for EMA. ${ }^{17-19}$

Group $3(n=64)$ : This group consisted of either pure mucinous carcinomas $(n=33)$ or carcinomas with MX mucinous and non-mucinous component $(n=31)$. The MX carcinoma group consisted of 25 MX mucinous and ductal carcinomas, 5 MX mucinous and micropapillary carcinomas and $1 \mathrm{MX}$ carcinoma with mucinous, micropapillary, and papillary morphology.

\section{Tissue Microarray}

Tissue microarrays (TMAs) with threefold redundancy were created for each group of cases. Three to six tissue cores each with a core diameter of $0.6 \mathrm{~mm}$ punched from representative tumor regions of each donor block were transferred and arrayed into a new recipient paraffin blocks using a tissue microarrayer
(Beecher Instruments, Sun Prairie, WI, USA). Group 1 cases (consecutive breast carcinoma) were arrayed on TMA-1, group 2 cases (micropapillary) were arrayed on TMA-2, group 3 pure and MX (with both mucinous and non-mucinous components) mucinous carcinomas were arrayed on TMA-3A and TMA-3B.

\section{Immunohistochemistry}

All TMA sections were subjected to immunohistochemical staining for WT1 (clone 6F-H2, predilute; Cell Marque, Hot Springs, AR, USA). TMA-2 was also stained with EMA (E29, predilute; Ventana Medical Systems, Tucson, AZ, USA).

Four microns TMA sections were immunostained on the Benchmark ${ }^{\circledR}$ XT automated stainer (Ventana Medical Systems). The WT1 protocol consisted of a pretreatment with CC1, $\mathrm{pH}$ 8.0, combined with protease III (Ventana Medical Systems) followed by incubation with WT1 mouse monoclonal antibody. The antigen-antibody complexes were detected using an $i$ VIEW $^{\mathrm{TM}}$ DAB detection kit (Ventana Medical Systems).

EMA was used only as an adjunct for correct classification of cases in the micropapillary TMA (TMA-2). EMA staining was performed using the same platform as WT1 and required no pretreatment. All cases classified as either pure micropapillary or with micropapillary component showed 'reverse polarity' with EMA.

\section{Scoring}

Hormone receptor studies were performed at the time of initial diagnosis. Estrogen and progesterone receptors were scored using a semiquantitative scoring system similar to previously described H-score methodology. ${ }^{20}$ This method takes into account percentage as well as intensity of staining. The percentage of positive cells was multiplied by the intensity of staining $(0,1+, 2+$, or $3+)$, followed by addition of all the values. Therefore, the score ranged from 0 (no staining) to 300 (diffuse strong staining). A score of 11 or more was considered as positive. The positive staining was further subdivided into weak (score of 11-50), moderate (score of 51-199), and strong (score of 200 or more) expression for statistical analysis. HER2 was considered as positive if tumor showed a $3+$ immunohistochemical score or gene amplification by fluorescence in situ hybridization.

WT1 staining was also assessed using a criterion similar to the hormone receptors and the positive staining was similarly subdivided into weak (score of 11-50), moderate (score of 51-199), and strong (score of 200 or more). Only nuclear WT1 staining was scored. The rationale behind this subdivision was that ovarian serous carcinomas generally show a WT1 score of 200 or more, and our intent was to 
determine whether WT1 staining in breast carcinoma would cause a problem in differential diagnosis with ovarian tumors in a metastatic setting.

\section{Cellularity Assessment}

All available tumor slides were reviewed. For pure mucinous carcinomas, the percentage of mucin (without cells) was subtracted from the entire tumor $(100 \%)$ to calculate percentage tumor cellularity. For MX carcinomas, the percentage of mucinous carcinoma (both mucin and cells floating within mucin) was subtracted from the entire tumor (100\%) to calculate the percentage of non-mucinous component.

\section{Statistical Analysis}

Statistical analysis was performed using the Arcus Quickstat software program (Longman Software Publishing, Cambridge, England). The differences between WT1-positive and WT1-negative tumors (in both pure and MX mucinous carcinoma subtypes) with respect to known prognostic variables were analyzed using $\chi^{2} /$ Fisher's exact test. Statistical significance was defined as a $P$-value less than 0.05 .

\section{Results}

WT1 expression in various breast tumor subtypes is summarized in Table 1. Among the group of

Table 1 WT1 expression in breast carcinoma $(n=153)$

\begin{tabular}{lc}
\hline Tumor group & WT1 positivity \\
\hline Group 1 (consecutive breast carcinoma) & $1 / 63(2 \%)^{\mathrm{a}}$ \\
Group 2 (micropapillary carcinoma) & $2 / 20(10 \%)^{\mathrm{b}}$ \\
Group 2 (no special type with retraction artifacts) & $0 / 6(0 \%)$ \\
Group 3 (pure mucinous carcinoma) & $21 / 33(64 \%)$ \\
Group 3 (mucinous mixed with other types) & $9 / 31(29 \%)$
\end{tabular}

${ }^{\mathrm{a}}$ This tumor was also a pure mucinous carcinoma.

${ }^{b}$ Both of these tumors were mixed mucinous and micropapillary carcinomas.
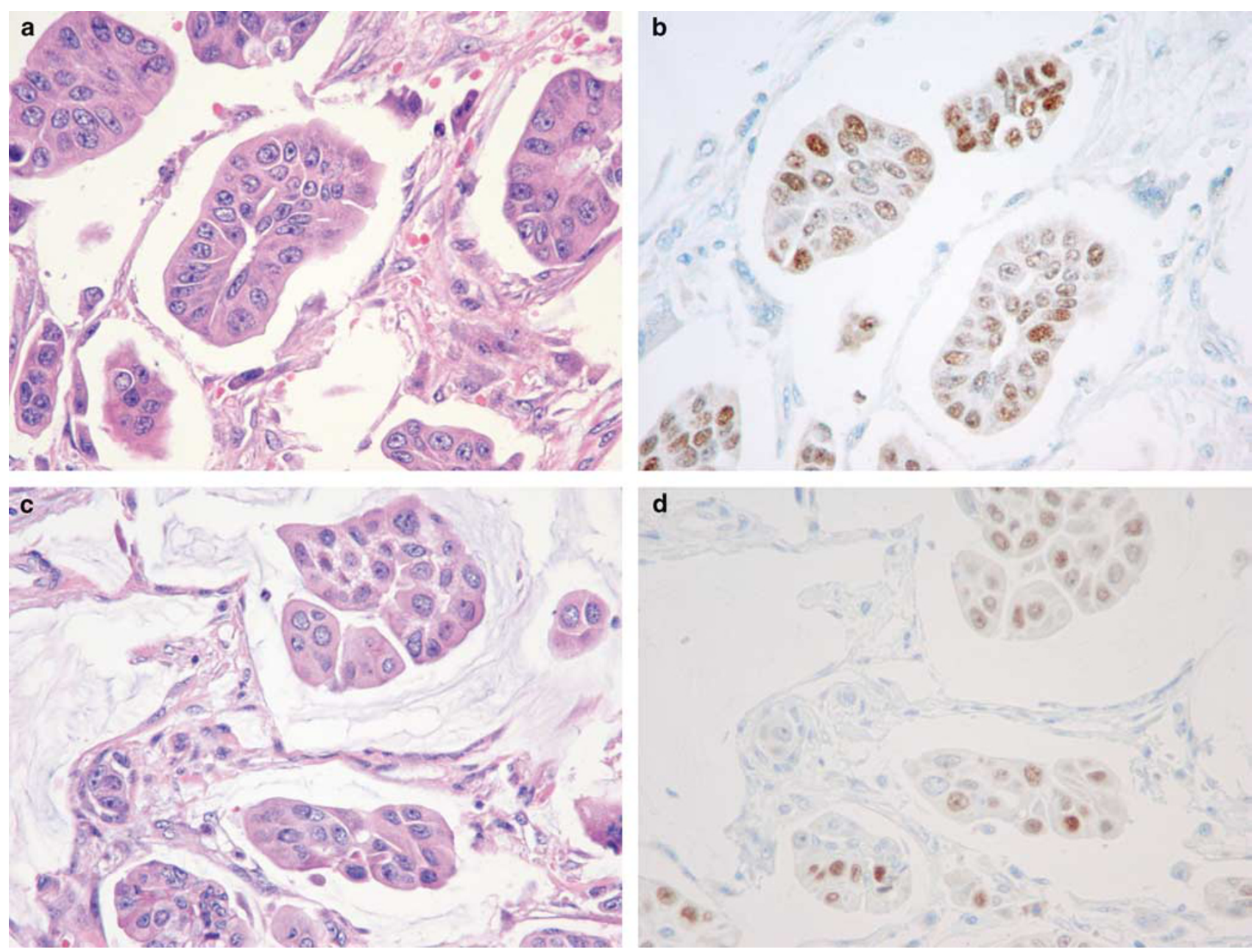

Figure 1 A MX micropapillary (a and b; $\times 400$, H\&E and anti-WT1) and mucinous (c and d; $\times 400$, H\&E and anti-WT1) carcinoma demonstrating weak to moderate staining for WT1 in both components. 
consecutive breast carcinomas (group 1), only 1 of $63(1.6 \%)$ cases showed WT1 expression. This tumor was a pure mucinous carcinoma. Among the micropapillary group (group 2), 2 of $20(10 \%)$ tumors showed WT1 expression. Both tumors showed a MX micropapillary and mucinous morphology and WT1 expression was seen in both components (Figure 1). All ductal tumors with retraction artifacts in group 2 (six in number) were negative for WT1.

The tumors that showed WT1 expression were predominantly from group 3 (mucinous tumors). They were either pure mucinous carcinomas or tumors that show MX morphology comprising of mucinous and non-mucinous components. Among the pure mucinous carcinomas, overwhelming majority of cases $(21 / 33 ; 64 \%)$ showed WT1 nuclear expression (Figure 2). WT1 immunohistochemical score ranged from 15 to 210 , with a mean score of 88.6 and a median score of 90 . Using a three-tiered scoring system (discussed in the Materials and methods section), 7 cases showed weak WT1 expression (33\%), 13 cases showed moderate WT1 expression (62\%), and only 1 case showed strong
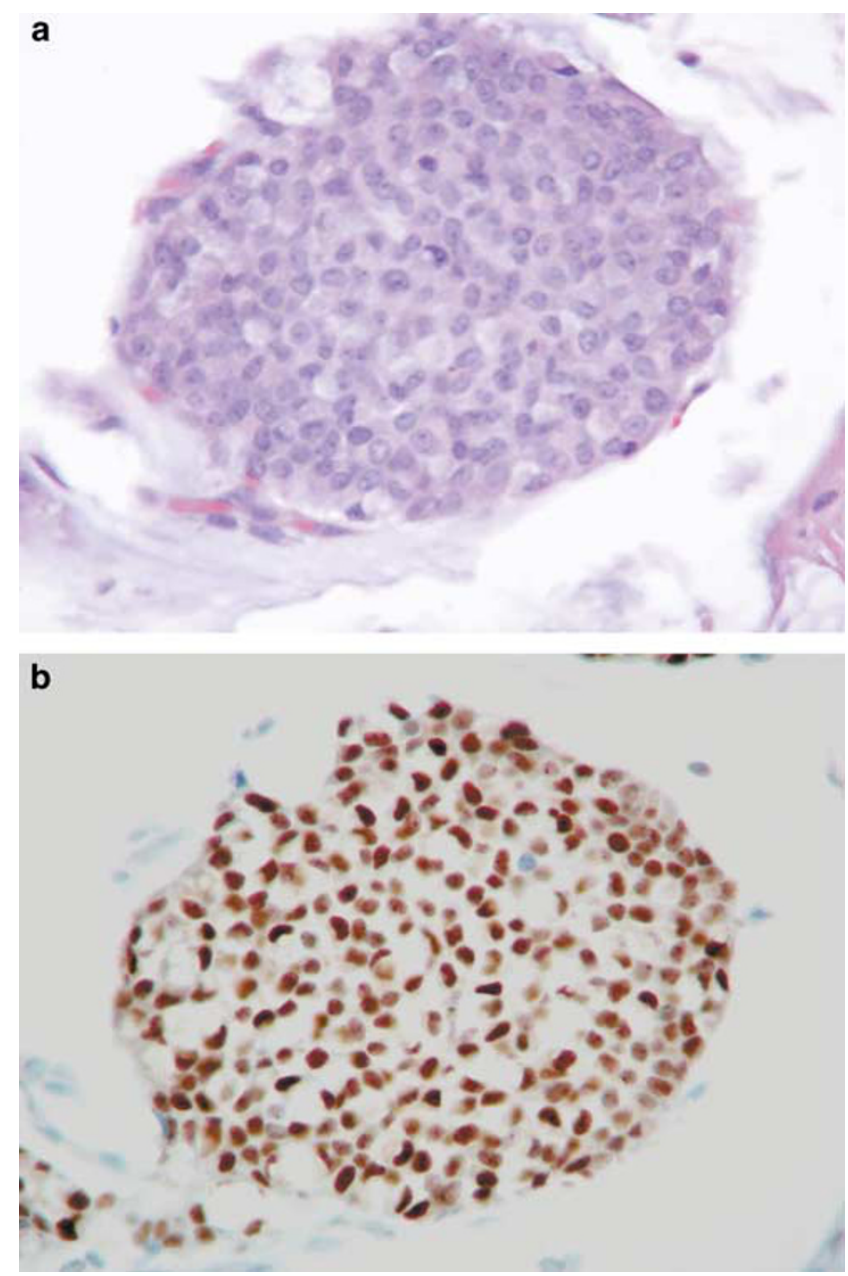

Figure 2 A pure mucinous carcinoma $(\mathbf{a} ; \times 400$, H\&E) demonstrating strong WT1 expression (b; $\times 400$, anti-WT1).
WT1 expression (5\%). In this group of pure mucinous carcinoma, WT1 expression was significantly associated with low Nottingham grade $(P=0.01)$ and lower percentage cellularity $(P=0.01)$. The result for other variables was not statistically significant (Table 2).

Among the MX (mucinous and non-mucinous) carcinomas in group 3, WT1 nuclear expression was identified in 9 of $31(29 \%)$ cases. The WT1 immunohistochemical score for this group ranged from 20 to 220, with a mean score of 99.4 and a median score of 80 . Using a three-tiered scoring system, three cases showed weak WT1 expression $(33 \%)$, five cases showed moderate WT1 expression $(56 \%)$, and only one case showed strong WT1 expression $(11 \%)$. Of these nine MX carcinomas positive for WT1, eight were MX mucinous and ductal carcinomas, and one was a MX mucinous, micropapillary, and papillary carcinoma. The WT1 immunohistochemical score in the mucinous and non-mucinous component was similar in seven cases (Figure 3) and in two cases, mucinous component stained slightly stronger than the nonmucinous component. Similar to pure mucinous carcinoma group, WT1 expression was again significantly associated with low Nottingham grade $(P=0.04)$ and patient aged more than 55 years. The result for other variables was not statistically significant (Table 3).

Table 2 Clinical and pathological characteristics of WT1-positive $(n=21)$ vs WT1-negative $(n=12)$ pure mucinous carcinomas

\begin{tabular}{|c|c|c|c|}
\hline & $\begin{array}{l}\text { WT1 positive } \\
(\mathrm{n}=21)\end{array}$ & $\begin{array}{l}\text { WT1 negative } \\
(\mathrm{n}=12)\end{array}$ & $\mathrm{P}$-value \\
\hline Nottingham grade & $\begin{array}{l}\text { Grade } 1: 11(52 \%) \\
\text { Grade 2: } 9(43 \%) \\
\text { Grade } 3: 1(5 \%)\end{array}$ & $\begin{array}{l}\text { Grade 1: } 1(8 \%) \\
\text { Grade 2: } 9(75 \%) \\
\text { Grade 3: } 2(17 \%)\end{array}$ & $0.01^{*}$ \\
\hline Tumor size & $\begin{array}{l}\leq 2 \mathrm{~cm}: 18(86 \%) \\
>2 \mathrm{~cm}: 3(14 \%)\end{array}$ & $\begin{array}{l}\leq 2 \mathrm{~cm}: 7(58 \%) \\
>2 \mathrm{~cm}: 5(42 \%)\end{array}$ & 0.10 \\
\hline Percentage cellularity & $\begin{array}{l}\leq 50 \%: 18(86 \%) \\
>50 \%: 3(14 \%)\end{array}$ & $\begin{array}{l}\leq 50 \%: 5(42 \%) \\
>50 \%: 7(58 \%)\end{array}$ & $0.01^{*}$ \\
\hline Estrogen receptor & $\begin{array}{l}\text { Weak: } 1(5 \%) \\
\text { Moderate: } 5(25 \%) \\
\text { Strong: } 14(70 \%) \\
\text { Negative: } 0(0 \%) \\
\text { Unknown: } 1\end{array}$ & $\begin{array}{l}\text { Weak: } 0(0 \%) \\
\text { Moderate: } 4(36 \%) \\
\text { Strong: } 7(64 \%) \\
\text { Negative: } 0(0 \%) \\
\text { Unknown: } 1\end{array}$ & 0.94 \\
\hline $\begin{array}{l}\text { Progesterone } \\
\text { receptor }\end{array}$ & $\begin{array}{l}\text { Weak: } 3(15 \%) \\
\text { Moderate: } 8(40 \%) \\
\text { Strong: } 8(40 \%) \\
\text { Negative: } 1(5 \%) \\
\text { Unknown: } 1\end{array}$ & $\begin{array}{l}\text { Weak: } 6(55 \%) \\
\text { Moderate: } 2(18 \%) \\
\text { Strong: } 1(9 \%) \\
\text { Negative: } 2(18 \%) \\
\text { Unknown: } 1\end{array}$ & 0.23 \\
\hline HER2 & $\begin{array}{l}\text { Negative: } 20(100 \%) \\
\text { Positive: } 0(0 \%) \\
\text { Unknown: } 1\end{array}$ & $\begin{array}{l}\text { Negative: } 10(91 \%) \\
\text { Positive: } 1(9 \%) \\
\text { Unknown: } 1\end{array}$ & 0.35 \\
\hline Nodal status & $\begin{array}{l}\text { Negative: } 14(100 \%) \\
\text { Positive: } 0(0 \%) \\
\text { Unknown: } 7\end{array}$ & $\begin{array}{l}\text { Negative: } 7(70 \%) \\
\text { Positive: } 3(30 \%) \\
\text { Unknown: } 2\end{array}$ & 0.05 \\
\hline Age & $\begin{array}{l}\leq 55 \text { years: } 7(33 \%) \\
>55 \text { years: } 14(67 \%)\end{array}$ & $\begin{array}{l}\leq 55 \text { years: } 5(42 \%) \\
>55 \text { years: } 7(58 \%)\end{array}$ & 0.70 \\
\hline
\end{tabular}

* Statistically significant $P$-value. 

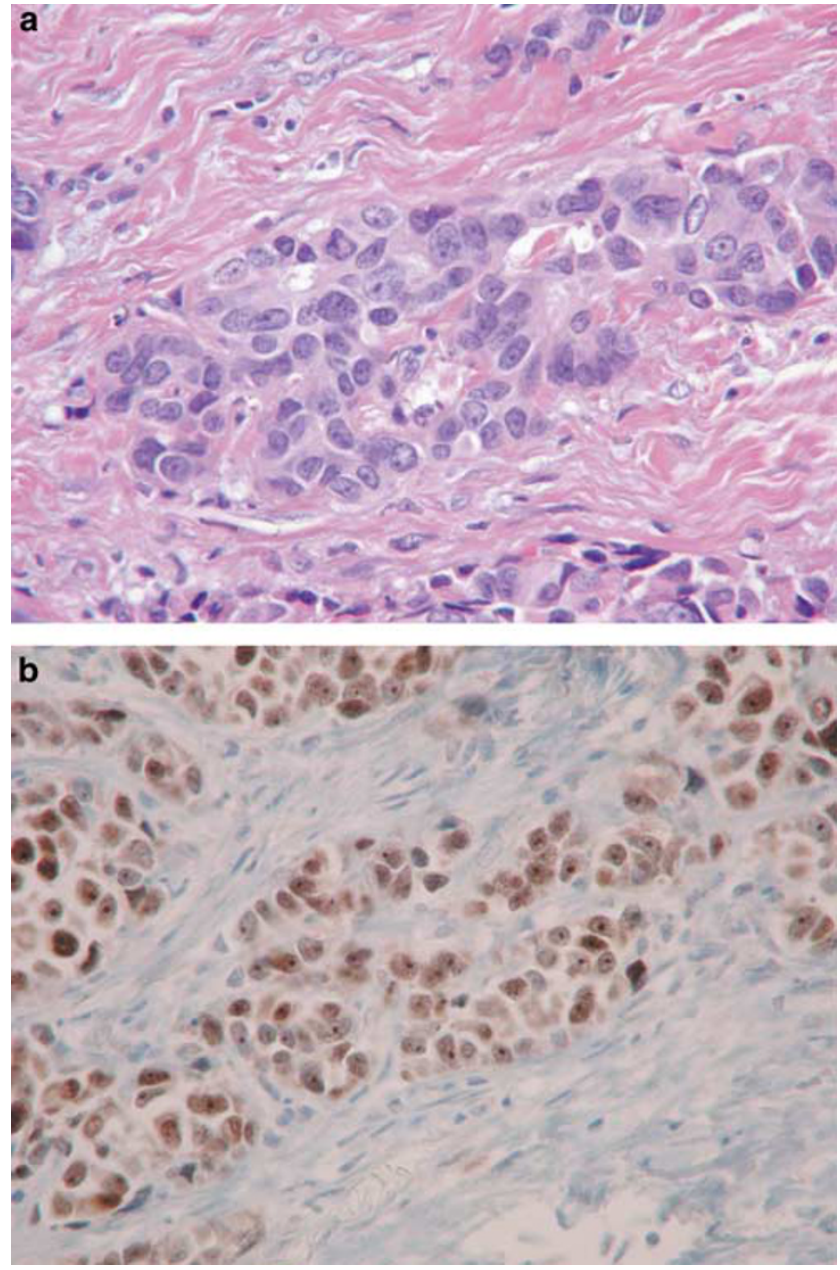

Figure 3 Non-mucinous component $(\mathbf{a} ; \times 400, \mathrm{H} \& \mathrm{E})$ of a MX mucinous and ductal no special type carcinoma demonstrating moderate WT1 expression (b; $\times 400$, anti-WT1). Mucinous component is not shown but stained similarly.

\section{Discussion}

This is the first comprehensive study that has analyzed WT1 expression in breast carcinoma subtypes. We convincingly demonstrate that WT1 expression in breast carcinomas is predominantly seen in mucinous carcinomas. The expression is seen in up to two-third of pure mucinous carcinomas and in approximately one-third of MX mucinous carcinomas. When expression is seen in MX carcinomas, the non-mucinous component is generally a no special type ductal carcinoma or a micropapillary carcinoma. However, all 18 pure micropapillary carcinomas and MX micropapillary carcinomas with ductal carcinomas in our study were negative for WT1 expression. Recently, Lee et $a 1^{15}$ reported WT1 expression in invasive micropapillary carcinomas. They analyzed 34 cases and found weak to moderate expression in $1-10 \%$ of the cells in 9 cases. It appears that many, if not all, of these cases would be considered negative by
Table 3 Clinical and pathological characteristics of WT1-positive $(n=9)$ vs WT1-negative $(n=22)$ mixed mucinous and nonmucinous carcinomas

\begin{tabular}{|c|c|c|c|}
\hline & $\begin{array}{l}\text { WT1 positive } \\
(\mathrm{n}=9)\end{array}$ & $\begin{array}{l}\text { WT1 negative } \\
(\mathrm{n}=22)\end{array}$ & $\mathrm{P}$-value \\
\hline Nottingham grade & $\begin{array}{l}\text { Grade 1: } 5(56 \%) \\
\text { Grade 2: } 4(44 \%) \\
\text { Grade 3: } 0(0 \%)\end{array}$ & $\begin{array}{l}\text { Grade 1: } 7(32 \%) \\
\text { Grade 2: } 6(27 \%) \\
\text { Grade 3: } 9(41 \%)\end{array}$ & $0.04^{*}$ \\
\hline Tumor size & $\begin{array}{l}\leq 2 \mathrm{~cm}: 8(89 \%) \\
>2 \mathrm{~cm}: 1(11 \%)\end{array}$ & $\begin{array}{l}\leq 2 \mathrm{~cm}: 15(68 \%) \\
>2 \mathrm{~cm}: 7(32 \%)\end{array}$ & 0.30 \\
\hline $\begin{array}{l}\text { Percentage of } \\
\text { non-mucinous } \\
\text { component }\end{array}$ & $\leq 50 \%: 3(33 \%)$ & $>50 \%: 14(63 \%)$ & 1 \\
\hline Estrogen receptor & $\begin{array}{l}\text { Weak: } 0(0 \%) \\
\text { Moderate: } 2(22 \%) \\
\text { Strong: } 7(78 \%) \\
\text { Negative: } 0(0 \%)\end{array}$ & $\begin{array}{l}\text { Weak: } 1(5 \%) \\
\text { Moderate: } 5(23 \%) \\
\text { Strong: } 14(67 \%) \\
\text { Negative: } 1(5 \%) \\
\text { Unknown: } 1\end{array}$ & 0.78 \\
\hline $\begin{array}{l}\text { Progesterone } \\
\text { receptor }\end{array}$ & $\begin{array}{l}\text { Weak: } 2(22 \%) \\
\text { Moderate: } 3(33 \%) \\
\text { Strong: } 4(45 \%) \\
\text { Negative: } 0(0 \%)\end{array}$ & $\begin{array}{l}\text { Weak: } 3(13 \%) \\
\text { Moderate: } 6(29 \%) \\
\text { Strong: } 6(29 \%) \\
\text { Negative: } 6(29 \%) \\
\text { Unknown: } 1\end{array}$ & 0.21 \\
\hline HER2 & $\begin{array}{l}\text { Negative: } 9(100 \%) \\
\text { Positive: } 0(0 \%)\end{array}$ & $\begin{array}{l}\text { Negative: } 20(91 \%) \\
\text { Positive: } 2(9 \%)\end{array}$ & 1 \\
\hline Nodal status & $\begin{array}{l}\text { Negative: } 5(71 \%) \\
\text { Positive: } 2(29 \%) \\
\text { Unknown: } 2\end{array}$ & $\begin{array}{l}\text { Negative: } 12(67 \%) \\
\text { Positive: } 6(33 \%) \\
\text { Unknown: } 4\end{array}$ & 1 \\
\hline Age & $\begin{array}{l}\leq 55 \text { years: } 1(11 \%) \\
>55 \text { years: } 8(89 \%)\end{array}$ & $\begin{array}{l}\leq 55 \text { years: } 12(55 \%) \\
>55 \text { years: } 10(45 \%)\end{array}$ & $0.04^{*}$ \\
\hline
\end{tabular}

* Statistically significant $P$-value.

our criteria (a score of 11 considered positive). Therefore, we do not believe that there is any discordance between our study and Lee et al's study, but it is rather the effect of a more stringent and objective scoring criteria in our study that is responsible for this subtle difference. Unfortunately, Lee et al did not examine mucinous carcinomas for WT1 expression.

We also analyzed WT1 expression with respect to various clinical-pathological parameters. WT1 expression showed statistically significant association with lower tumor grade and lower percentage tumor cellularity in pure mucinous carcinoma (Table 2). For MX carcinomas, WT1 expression was associated to lower tumor grade and older age (Table 2). There was no correlation with hormone receptor status, tumor size, nodal status, and HER2 expression.

WT1 expression in mucinous breast carcinomas in itself is a novel and surprise finding, and the similar degree of WT1 expression in the nonmucinous component is even more intriguing. Studies have shown a relatively poor prognosis of the MX mucinous carcinomas compared to pure mucinous carcinomas. ${ }^{21}$ It is possible that the subset of these MX mucinous tumors that show WT1 expression are more closely related to pure mucinous carcinomas than to the non-mucinous component would otherwise suggest. A prime 
example of this controversy is the entity of MX micropapillary and mucinous carcinoma. Previous studies have suggested that these tumors should be considered as invasive micropapillary carcinomas with mucinous differentiation, as their behavior (ie, higher frequency of lymph node metastasis) is more similar to pure micropapillary carcinomas. ${ }^{18,22} \mathrm{We}$ believe this issue should be further analyzed in context of WT1 expression, especially because of statistically significant association between WT1 expression and low tumor grade. In our current study, there were a total of eight MX mucinous and micropapillary carcinomas. Of these, five were negative for WT1 and three were positive for WT1. Of the five tumors negative for WT1, lymph node status was available on three cases and all had lymph node metastases (two pN1mi, one pN1). Of the three WT1-positive cases, one case was negative for lymph node metastasis and the other two showed micrometastasis. These case numbers are too small to make any meaningful conclusion, but a larger data set need to be analyzed in conjunction with WT1 expression.

A similar degree of WT1 expression in the nonmucinous component of a MX carcinoma is of some concern for the differential diagnosis in a carcinoma of an unknown primary site. As mentioned earlier, we analyzed our results using a semiquantitative method that enable us to address this important issue. Our results show that a total of 33 carcinomas were positive for WT1 expression. Of these 33, only $2(6 \%)$ tumors showed strong WT1 expression, that is, an immunohistochemical score of 200 or more. In contrast, majority ( $\sim 90 \%$ ) of non-endometrial mullerian serous carcinomas show diffuse strong WT1 expression. ${ }^{4,5}$ Therefore, the degree of WT1 expression can still help differentiate between a breast primary and a mullerian primary tumor. Only caveat is that endometrial serous carcinomas can show WT1 expression in approximately $20 \%$ of cases and majority of these tumors would show only moderate expression of WT1 protein. ${ }^{23,24}$

WT1 gene has been widely accepted to have a tumor suppressor role in the formation of Wilms' tumor, but in other solid tumors, some recent studies have suggested an oncogenic role. ${ }^{25,26}$ The exact reason for WT1 expression in mucinous breast carcinoma remains uncertain, but we speculate an oncogenic role of WT1 protein because of its expression in one particular morphologic type of tumor and absence of WT1 expression in normal breast luminal epithelium.

Another aspect of WT1 expression in any malignant tumor is that it raises some hope regarding treatment. With the confirmed expression of WT1derived peptides on malignant cell surfaces and the recognition of these peptides by cellular and humoral immune responses, several studies suggest that WT1 may be a promising potential target antigen in immunotherapeutic trials. ${ }^{13,14,27-31}$ As far as mucinous breast carcinoma is concerned, WT1 immunotherapy appears to be an attractive targeted therapy as these tumors occur predominantly in the elderly population, where the choice of safe chemotherapeutic regimen is rather limited. However, it is still not clear if these patients with relatively indolent tumor type might benefit.

In summary, WT1 expression in breast carcinoma is seen predominantly in the mucinous subtype. The degree of expression is generally moderate and therefore would not be a major issue in the differential diagnosis from an ovarian primary, especially if combined with other breast-specific markers. ${ }^{32}$ With the advent of use of WT1 peptide immunotherapy in malignancies, expression of WT1 in mucinous breast carcinomas provides a molecular target in these relatively indolent breast tumors.

\section{References}

1 Pelletier J, Bruening W, Li FP, et al. WT1 mutations contribute to abnormal genital system development and hereditary Wilms' tumour. Nature 1991;353:431-434.

2 Pritchard-Jones K, Fleming S, Davidson D, et al. The candidate Wilms' tumour gene is involved in genitourinary development. Nature 1990;346:194-197.

3 Rose EA, Glaser T, Jones C, et al. Complete physical map of the WAGR region of $11 \mathrm{p} 13$ localizes a candidate Wilms' tumor gene. Cell 1990;60:495-508.

4 Goldstein NS, Uzieblo A. WT1 immunoreactivity in uterine papillary serous carcinomas is different from ovarian serous carcinomas. Am J Clin Pathol 2002; 117:541-545.

5 Acs G, Pasha T, Zhang PJ. WT1 is differentially expressed in serous, endometrioid, clear cell, and mucinous carcinomas of the peritoneum, fallopian tube, ovary, and endometrium. Int J Gynecol Pathol 2004;23:110-118.

6 Hwang H, Quenneville L, Yaziji H, et al. Wilms tumor gene product: sensitive and contextually specific marker of serous carcinomas of ovarian surface epithelial origin. Appl Immunohistochem Mol Morphol 2004;12:122-126.

7 Hylander B, Repasky E, Shrikant P, et al. Expression of Wilms tumor gene (WT1) in epithelial ovarian cancer. Gynecol Oncol 2006;101:12-17.

8 Kumar-Singh S, Segers K, Rodeck U, et al. WT1 mutation in malignant mesothelioma and WT1 immunoreactivity in relation to p53 and growth factor receptor expression, cell-type transition, and prognosis. J Pathol 1997;181:67-74.

9 Inoue K, Ogawa H, Sonoda Y, et al. Aberrant overexpression of the Wilms tumor gene (WT1) in human leukemia. Blood 1997;89:1405-1412.

10 Miyoshi Y, Ando A, Egawa C, et al. High expression of Wilms' tumor suppressor gene predicts poor prognosis in breast cancer patients. Clin Cancer Res 2002;8:1167-1171.

11 Nakatsuka S, Oji Y, Horiuchi T, et al. Immunohistochemical detection of WT1 protein in a variety of cancer cells. Mod Pathol 2006;19:804-814.

12 Oji Y, Ogawa H, Tamaki H, et al. Expression of the Wilms' tumor gene WT1 in solid tumors and its involvement in tumor cell growth. Jpn J Cancer Res 1999;90:194-204. 
13 Oka Y, Tsuboi A, Kawakami M, et al. Development of WT1 peptide cancer vaccine against hematopoietic malignancies and solid cancers. Curr Med Chem 2006;13:2345-2352.

14 Sugiyama H. Cancer immunotherapy targeting Wilms' tumor gene WT1 product. Expert Rev Vaccines 2005;4:503-512.

15 Lee AH, Paish EC, Marchio C, et al. The expression of Wilms' tumour-1 and Ca125 in invasive micropapillary carcinoma of the breast. Histopathology 2007;51: 824-828.

16 Karabakhtsian R, Bhargava R. WT-1 expression in primary invasive breast carcinoma: occasional expression in micropapillary and mucinous subtypes. Mod Pathol 2007;20(Suppl 2):38A; abstract 151.

17 Luna-More S, Gonzalez B, Acedo C, et al. Invasive micropapillary carcinoma of the breast. A new special type of invasive mammary carcinoma. Pathol Res Pract 1994;190:668-674.

18 Nassar H. Carcinomas with micropapillary morphology: clinical significance and current concepts. Adv Anat Pathol 2004;11:297-303.

19 Nassar H, Pansare V, Zhang H, et al. Pathogenesis of invasive micropapillary carcinoma: role of MUC1 glycoprotein. Mod Pathol 2004;17:1045-1050.

20 McCarty Jr KS, Miller LS, Cox EB, et al. Estrogen receptor analyses. Correlation of biochemical and immunohistochemical methods using monoclonal antireceptor antibodies. Arch Pathol Lab Med 1985; 109:716-721.

21 Toikkanen S, Kujari H. Pure and mixed mucinous carcinomas of the breast: a clinicopathologic analysis of 61 cases with long-term follow-up. Hum Pathol 1989;20:758-764.

22 Nassar H, Wallis T, Andea A, et al. Clinicopathologic analysis of invasive micropapillary differentiation in breast carcinoma. Mod Pathol 2001;14:836-841.
23 Dupont J, Wang X, Marshall DS, et al. Wilms tumor gene (WT1) and p53 expression in endometrial carcinomas: a study of 130 cases using a tissue microarray. Gynecol Oncol 2004;94:449-455.

24 Egan JA, Ionescu MC, Eapen E, et al. Differential expression of WT1 and p53 in serous and endometrioid carcinomas of the endometrium. Int J Gynecol Pathol 2004;23:119-122.

25 Hohenstein P, Hastie ND. The many facets of the Wilms' tumour gene, WT1. Hum Mol Genet 2006;15 (Spec. no. 2):R196-R201.

26 Loeb DM, Sukumar S. The role of WT1 in oncogenesis: tumor suppressor or oncogene? Int J Hematol 2002;76: 117-126.

27 Fujiki F, Oka Y, Tsuboi A, et al. Identification and characterization of a WT1 (Wilms tumor gene) proteinderived HLA-DRB1*0405-restricted 16-mer helper peptide that promotes the induction and activation of WT1-specific cytotoxic T lymphocytes. J Immunother 2007;30:282-293.

28 Hutchings Y, Osada T, Woo CY, et al. Immunotherapeutic targeting of Wilms' tumor protein. Curr Opin Mol Ther 2007;9:62-69.

29 Oka Y, Tsuboi A, Taguchi T, et al. Induction of WT1 (Wilms' tumor gene)-specific cytotoxic T lymphocytes by WT1 peptide vaccine and the resultant cancer regression. Proc Natl Acad Sci USA 2004;101:13885-13890.

30 Xue S, Gao L, Gillmore R, et al. WT1-targeted immunotherapy of leukaemia. Blood Cells Mol Dis 2004;33:288-290.

31 Morita S, Oka Y, Tsuboi A, et al. A phase I/II trial of a WT1 (Wilms' tumor gene) peptide vaccine in patients with solid malignancy: safety assessment based on the phase I data. Jpn J Clin Oncol 2006;36:231-236.

32 Bhargava R, Dabbs DJ. Use of immunohistochemistry in diagnosis of breast epithelial lesions. Adv Anat Pathol 2007;14:93-107. 